\title{
PIA DESIDERIA: ENTRE EL AGUARDIENTE Y LA VIDA ASCÉTICA. LAS CALAVERAS BORRACHAS CLAMAN POR EL CHINGUIRITO (MÉXICO, 1836)
}

\author{
PIA DESIDERIA: BETWEEN HARD LIQUOR AND THE ASCETIC LIFE. \\ LAS CALAVERAS BORRACHAS CLAMAN POR EL CHINGUIRITO (MÉXICO, 1836)
}

Andrea Montiel López

Universidad Nacional Autónoma de México

ABSTRACT - The allegory of the body as a prison of the soul was visually depicted as a skeleton that imprisons a figure with childish features. One of the earliest examples of this image is the emblem "Infelix ego homo!» included in Herman Hugo's Pia Desideria (1624); however the pictura was incorporated in other media and contexts allowing its survival even to the end of the 19th century. In Mexico, it evolved from an ascetic-moralistic book to a popular pamphlet of ghostly apparitions revealed in dreams. How did this emblem -based on Neoplatonic philosophy- evolve from a book written in Latin to a popular nineteenth century pamphlet? Did it conserve part of its original meaning?

KEYWORDS: Death; Soul; Hard Liquor; Mexico.

RESUMEN • La alegoría del cuerpo como cárcel del alma se representó visualmente como un esqueleto que aprisiona a una figura de rasgos infantiles. Uno de los ejemplos más tempranos de esta imagen lo encontramos en el libro de emblemas de Herman Hugo, el afamado Pia Desideria (1624), sin embargo, la pictura se trasladó a otros soportes y contextos lo que le permitió continuar vigente hasta finales del siglo XIX. En el caso mexicano pasó de una publicación de corte ascético-moral a una popular en la cual apariciones fantasmales se manifiestan a través de revelaciones oníricas. ¿Cómo fue que este emblema -con visos neoplatónicos- pasó de un libro en latín a una hoja popular decimonónica? ¿Conservó algo de su significado original?

PALABRAS CLAVES: Muerte; Alma; Aguardiente; México. 
Las imágenes han desempeñado funciones culturales a lo largo de la historia pues son un fenómeno visual vivo que transforma aspectos de la vida de hombre y la sociedad (García Mahíques, 2009: 18). Sin embargo, esta relación no es unilateral pues, así como son vehículo de cambios también son objeto de, en palabras del historiador Aby Warburg (18661929), una transformatio energetica por lo que tienen un pasado, presente y futuro situados en diversas dimensiones contextuales.

Warburg sugirió que la memoria era el vehículo a través del cual se gestaba dicha transformación, sin embargo, no se refería a una actividad mental individual sino a una proyección colectiva que propiciaba que determinadas representaciones siguieran con vida, se transformaran o se olvidaran. "El por qué las habían conservado o qué tanto se habían transformado al ser retomadas es lo que revelaba una 'psicología de la imagen', puesto que la sociedad vertía sus deseos en ellas” (Báez, 2012: 245-246).

La vigencia de determinados tipos iconográficos sucede gracias a que «las formas convencionales de la alegoría se fusionan $[\ldots]$ al tiempo que se ven estremecidas, negadas y transfiguradas ante los embates de los impulsos inventivos de [nuevas edades históricas]" (Méndez, 2006: 153). Ejemplo de ello es el emblema ${ }^{1}$ "Infelix ego homo!», el cual merece un estudio que se detenga en su origen, los medios de transmisión, usos y funciones y sus modificaciones al pasar a otros soportes [fig. 1]. Si bien, no es un análisis que pueda resolverse con facilidad, con el presente trabajo me propongo realizar un primer y breve acercamiento a la resignificación de este tipo. ${ }^{2}$

Los tipos iconográficos se codifican de acuerdo con la tradición cultural, en ellos observamos continuidades y variaciones a lo largo del tiempo, así como su vinculación con temas y valores específicos (García Mahíques, 2009: 38). Atendiendo a ello, no sería posible abarcar la especificidad de cada una de las múltiples obras que siguen el modelo de "Infelix ego homo!» y retoman la alegoría del cuerpo -simbolizado por un esqueleto- como cárcel del alma, por lo cual me detendré sólo en una de ellas exponiendo de manera breve los ejemplos que la anteceden.

Hasta el momento, he localizado siete obras con una temporalidad que va desde 1624 hasta 1888. En la mayoría, la escena principal se mantuvo casi intacta, en otras, se añadieron elementos. La que ahora me atañe se publicó en un impreso decimonónico mexicano titulado Las calaveras borrachas claman por el chinguirito. ¿ ¿Cómo fue que un emblema cristiano -con visos neoplatónicos- pasó de un libro publicado en latín a una hoja popular decimonónica? ¿Conservó algo de su significado original sobre todo considerando las diferencias en cuanto al contenido textual que lo acompaña?

1. La definición de emblema ha sido objeto de una profusa discusión que no amerita reproducirse en estas páginas, por lo que en el presente trabajo me refiero al emblema en su acepción básica como una expresión gráfico-literaria compuesta por tres elementos primordiales e interdependientes: mote o lema, pictura o imagen y epigrama.

2. Para profundizar la cuestión de la «vitalización, olvido, modificación o recreación de las convenciones o códigos» se recomienda ver García Mahíques, 2009: 249-257.

3. «El chinguirito o aguardiente de caña es una bebida resultado de destilaciones. Su aparición se remonta, por lo menos, a 1631 año en que se menciona por primera vez en una prohibición; no obstante, el término 'chinguirito' se usó a partir de 1714», en Juan Pedro Viqueira, ¿Relajados o reprimidos? Diversiones públicas y vida social en la ciudad de México durante el Siglo de las Luces, México, Fondo de Cultura Económica, 1987, p. 205. «Fue prohibido a finales del virreinato hasta que se permitió en 1795, aunque con un fuerte gravamen. Con la independencia se pretendió liberarlo de impuestos, algo que dependía de los frecuentes cambios de gobierno» (Galí, 2013: 46). 


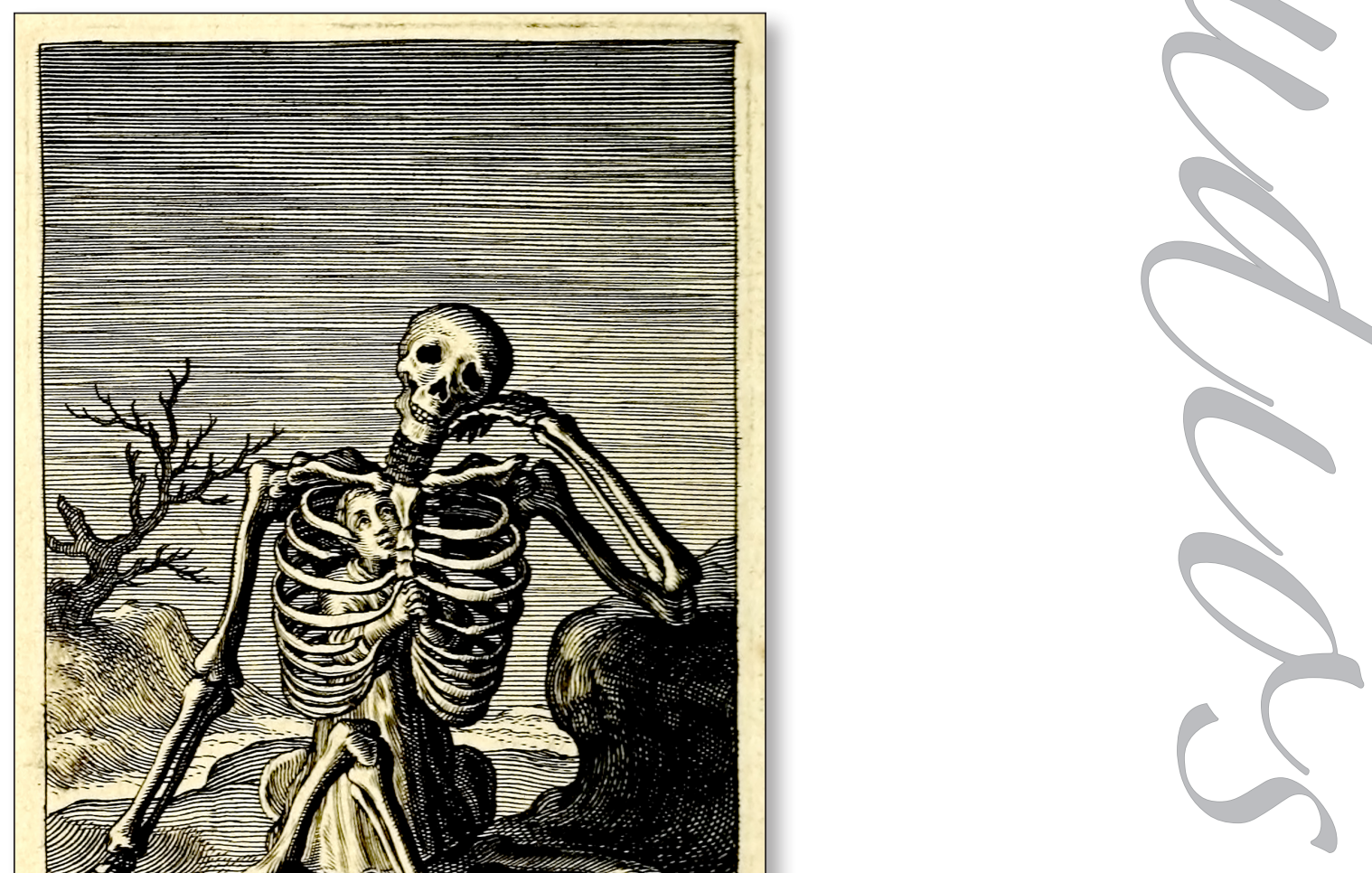

\section{DESEOS PIADOSOS: LA VIDA ASCÉTICA Y LA PERFECCIÓN ESPIRITUAL}

En 1531, el jurista milanés Andrea Alciato publicaba un libro sin imaginar que daría inicio a todo un género literario nuevo conocido como emblemática. Si bien, el Emblematum liber se nutría de lenguajes y tradiciones anteriores como la alegoría, los jeroglíficos egipcios, la lapidaria, la medallística, los bestiarios y los adagia, entre otros, significó un parteaguas en la manera de articular el texto con la imagen. Alciato expresó un objetivo eminentemente práctico para su obra pues afirmó: «he acuñado estos emblemas [...] para coserlos como

IMAGO, NÚM. II, 2019, I35-152 
cintas al vestido, como rótulos en los sombreros y que cualquiera pueda escribir con ellos callada escritura" (Sebastián López, 1994: 57).

La función humanista de los emblemas pasó a segundo plano cuando el movimiento contrarreformista y el Concilio de Trento $(1653)^{4}$ instituyeron la importancia de la imagen para fines didácticos y doctrinales (Sebastián López, 1981: 62-65). Asimismo, el método óptico-intuitivo de oración personal, propuesto por la devotio moderna y explotado en mayor medida por los seguidores de Ignacio de Loyola, encontró un fuerte apoyo en la imagen gráfica. En ese contexto, los libros de emblemas fueron una de las principales herramientas puesto que, además del binomio palabra-imagen, el ingenio de las analogías propiciaba el entretenimiento intelectual y un ejercicio mnemónico con objetivos moralizadores.

Gracias a este proceso la emblemática se popularizó y se amplió el tipo de público al que iba dirigido, sin embargo, seguía siendo un círculo restringido. Como explicara el tratadista Emanuele Tesauro estos símbolos "populares» con una oculta virtud para persuadir o disuadir, «son útiles para la pública enseñanza del pueblo» pero también especifica que "por popular, y por pueblo no debes entender la ignorante plebe, sino aquellos medianos ingenios, que puramente entienden latín, y de letras humanas» (Thesauro, 1741: 260-261).

En ese tenor, destacó una publicación que alcanzó un total de 150 reediciones y traducciones del latín a varios idiomas convirtiéndose en el libro de emblemas jesuita más difundido del siglo XVII: se trata de Pia Desideria (1624) de Herman Hugo. ${ }^{5}$ El Pia Desideria está compuesto por tres secciones que remiten a las tres vías para alcanzar la perfección espiritual; la primera, denominada vía penitente o purgativa, ${ }^{6}$ exalta la mortificación, la purificación de los sentidos y el dominio de las pasiones. La segunda, es la vía iluminativa ${ }^{7}$ que es la del conocimiento, la oración y la meditación; el último segmento corresponde a la vía unitiva ${ }^{8}$ que culmina con la perfección del alma y su unión con Dios (Sebastián López, 1981: 65-70).

La edición latina consta de 46 emblemas cuyas pictura fueron realizadas por el grabador flamenco Boetius Bolswert. Con respecto a las traducciones, tanto la alemana como la inglesa y la holandesa conservaron los mismos emblemas a diferencia de la castellana que suprimió precisamente el emblema que nos atañe. ${ }^{9}$ La obra pronto cruzó el Atlántico e inspiró muchas manifestaciones literarias y visuales, ejemplo de lo primero fue el libro Varón de deseos (1642) escrito por el obispo Juan de Palafox.

4. En la sesión XXV del Concilio de Trento se establece que: «Enseñen diligentemente los obispos que por medio de las historias de los misterios de nuestra redención, expresadas en pinturas y en otras imágenes, se instruye y confirma al pueblo los artículos de la fe, que deben ser recordados y meditados continuamente y que de todas las imágenes sagradas se saca gran fruto» (Sebastián López, 1981: 62-63).

5. <http://Www.unav.es/biblioteca/fondoantiguo/hufaexp20/Deleitando_ensena/Portada.html> 25-4-18. Algunos de los idiomas a los que se tradujo esta obra fueron: alemán, inglés, holandés, polaco, portugués y español.

6. Gemitus. Animae poenitentis (Sollozos/alma penitente)

7. Desideria. Animae sanctae (Deseos/alma sagrada)

8. Suspiria. Animae amantis (Suspiros/alma amante)

9. No me fue posible localizar las traducciones portuguesa y polaca que menciona Santiago Sebastián. Al castellano fue traducida por el jesuita Pedro Salas en 1638 bajo el título Affectos divinos con emblemas sagradas y se ilustró solamente con 45 emblemas. 


\section{ECOS DEL ASCETISMO: REPERCUSIONES ARTÍSTICAS}

El emblema está compuesto por tres elementos básicos: el lema o mote, la pictura o imagen y el epigrama, éstos son interdependientes y si alguno faltara el resultado sería "imperfecto». De acuerdo con Tesauro, la ausencia de una de las partes conduciría a la multiplicidad de significados de la imagen, de forma que "no puedes adivinar qual es el que yo entiendo". No obstante, admitía que podía subsistir sólo con la imagen sustituyendo el lema por el concepto mental de quien lo entiende (Thesauro, 1741: 260-262). Esta estructura permitió al emblema trasladarse a otros soportes como lienzos, relieves e incluso sermones u obras teatrales. Sin embargo, cuando se aparta de su contexto literario, entra en interacción con otros elementos que pueden modificar su significado.

Tal fue el caso del emblema "Infelix ego homo!» que, en origen, formaba parte del tercer capítulo de Pia Desideria. Este fue el punto de partida de una serie de imágenes que replican la pictura en la cual un esqueleto con postura melancólica mantiene cautiva a una figura infantil de gesto suplicante, personificación del alma. Esta era la traducción visual de una metáfora sugerida por Platón; el filósofo griego afirmó que «algunos llamaron al cuerpo tumba donde el alma está enterrada durante la vida presente»; agregó, además, que «el alma, mientras 'paga el castigo por aquello que debe pagar', tiene al cuerpo como un 'recinto' semejante a una 'prisión' donde está resguardada» (Pérez, 2012: 124).

Las ideas de Platón fueron recuperadas por pensadores cristianos de tradición senequista quienes recurrieron al concepto del cuerpo como cárcel del alma para

[...] hacer toda una disertación sobre el maltrato de lo físico para alcanzar la liberación del espíritu. La mortificación y la tortura del cuerpo fueron parte de una tradición espiritual cristiana, empeñada en doblegar los impulsos de la naturaleza biológica, en búsqueda de una perfección del alma para la cual el cuerpo era un lastre (Pérez, 2012: 123).

Tanto la representación visual como su significado se mantuvieron vigentes a lo largo de los siglos XVII y XVIII. Una de las interpretaciones más fieles al modelo grabado es la que se localiza en el convento de Santa Catalina en Arequipa, Perú. ${ }^{10}$ En el espacio conocido como la celda del padre Francisco de Salamanca se copiaron varios de los emblemas que ilustran el Pia Desideria, sin embargo, considero que la versión peruana debió tomarse de una edición latina diferente a la 1624 debido a la modificación de la postura del esqueleto. Mientras que aquella muestra al esqueleto en actitud melancólica, en el muro se observa un gesto más bien demostrativo mucho más cercano a otras ediciones como la de 1694 [figs. 2-3].

Las subsecuentes reinterpretaciones tienen cambios más notorios. Entre ellas está un impreso titulado Nueva relación y curioso romance, devoto y contemplativo, en que se escribe el Juicio Final escrito por Lucas del Olmo hacia la segunda mitad del siglo XVIII. El texto está dividido en dos partes; una se ilustró con una escena del juicio final y otra con dos emblemas tomados del Pia Desideria: "Infelix ego homo!» y "Dolores inferni circumdederunt me». A diferencia de este último que fue copiado íntegramente, el primero tiene un añadido por demás interesante.

10. Estudios más detallados de esta obra se encuentran en: Rafael García Mahíques, (1992: 83-114) y José Miguel Morales Folguera (2009: 79-97).

IMAGO, NÚM. II, 2019, I35-I52 


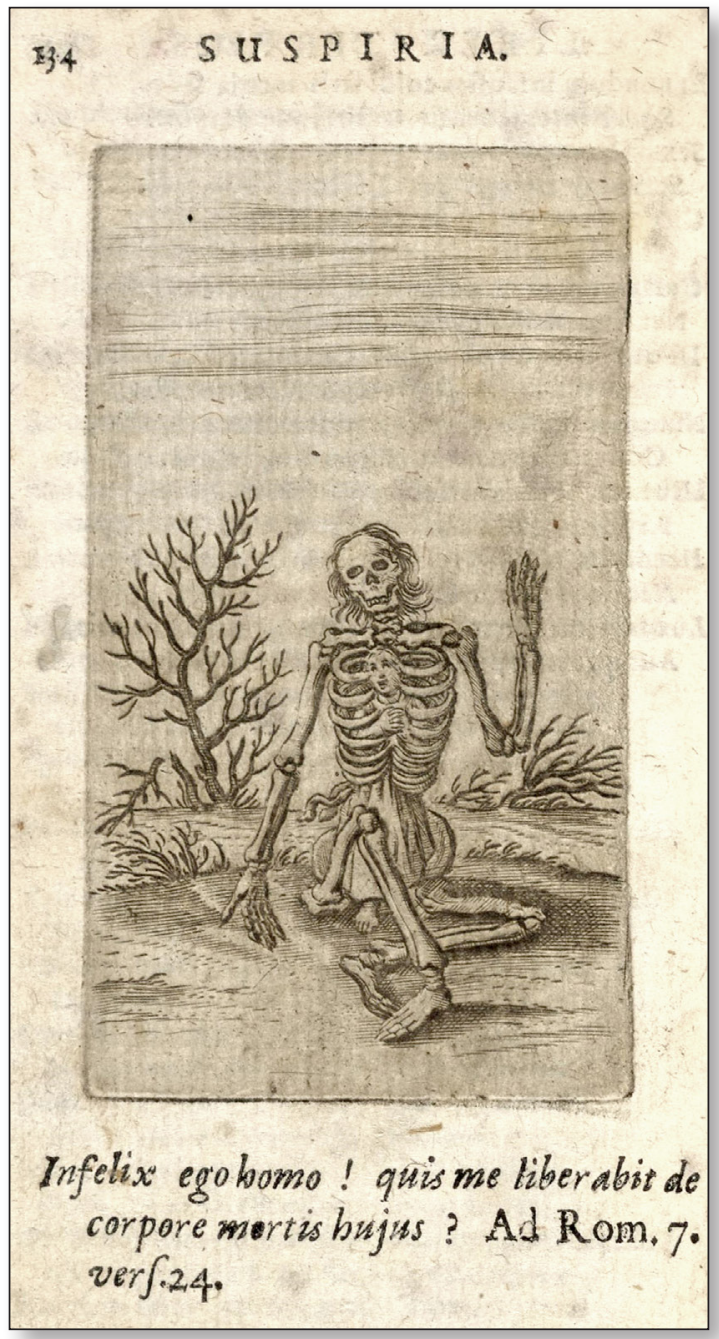

Fig. 2. Libro III, Emblema VIII «Infelix ego homo!», Herman Hugo, Pia Desideria, 1694.

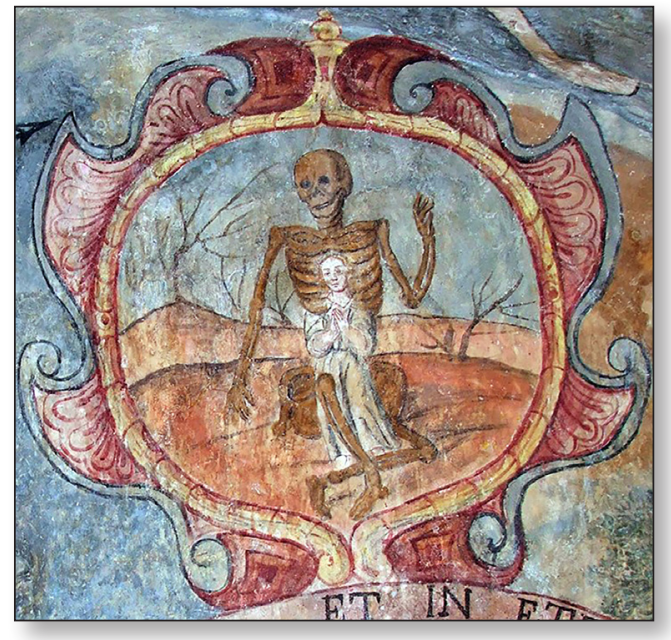

Fig. 3. Celda del padre Francisco de Salamanca, siglo XVIII, Convento de la Merced, Cuzco, Perú.

De la obra de Del Olmo localicé un ejemplar en la Biblioteca Nacional de España ${ }^{11}$ y otro fue reproducido por la investigadora Montserrat Galí en dos artículos de su autoría. ${ }^{12}$ Aunque el texto de ambos ejemplares tiene variaciones con respecto a la ortografía y puntuación, el contenido es el mismo por lo que podríamos pensar que se trata de ediciones diferentes, quizá una europea y otra novohispana ${ }^{13}$ [figs. 4-5].

Como indica el título, el tema principal es el juicio final, pasaje que el autor narra con toda amplitud especialmente en la segunda parte. Una lectura entre líneas nos da pistas de las razones por las cuales el autor pudo haber elegido dicho

emblema para ilustrar su obra pues al principio del Romance, Del Olmo destaca la corruptibilidad del cuerpo en contraste con la inmortalidad del alma (Olmo, ca. 1750-1800). Sin embargo, otro fragmento justificaría la necesidad de modificar la imagen al añadir, en la parte inferior, una escena del purgatorio y la boca del infierno que responden al interés por el destino de las almas tras el juicio universal:

11. El documento carece de información con respecto a la edición; tanto el lugar de impresión como la fecha, son desconocidos.

12. No fue posible ubicarlos en alguno de los dos recintos por lo que desconozco si la edición que reprodujo se trata de un ejemplar europeo o uno impreso en la Nueva España (Galí, 2013: 46) y (Galí, 2008: 61).

13. En la edición de posible factura novohispana se omitió el emblema "Dolores inferni circumdederunt me». 


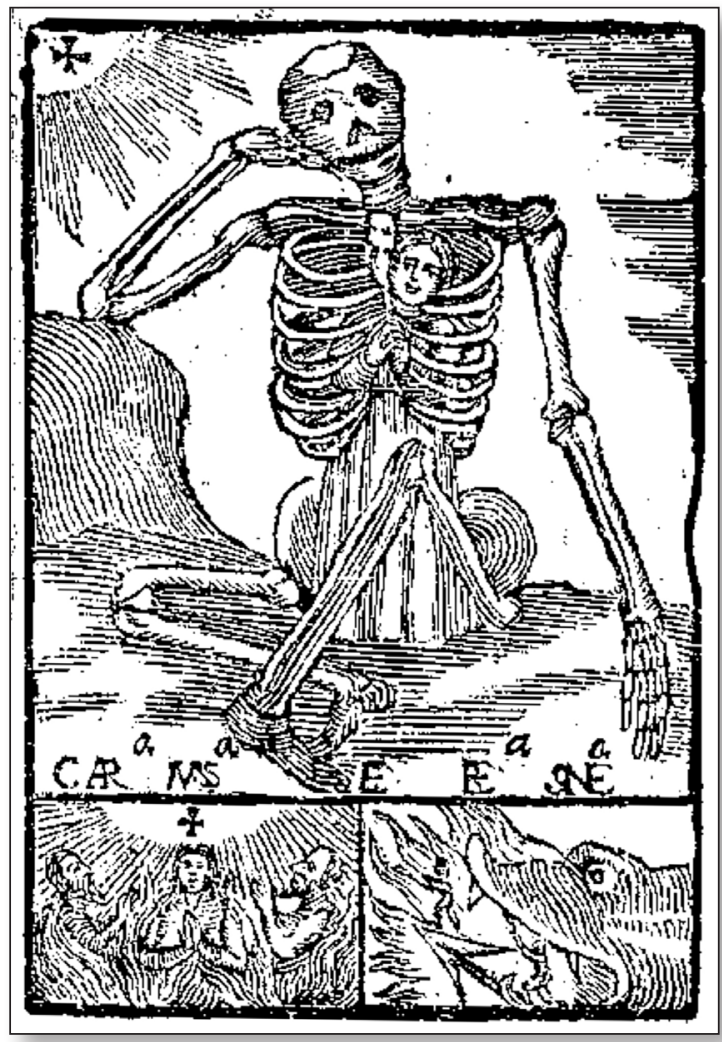

Fig. 4. Lucas del Olmo, El Juicio Final, Biblioteca Nacional de España.

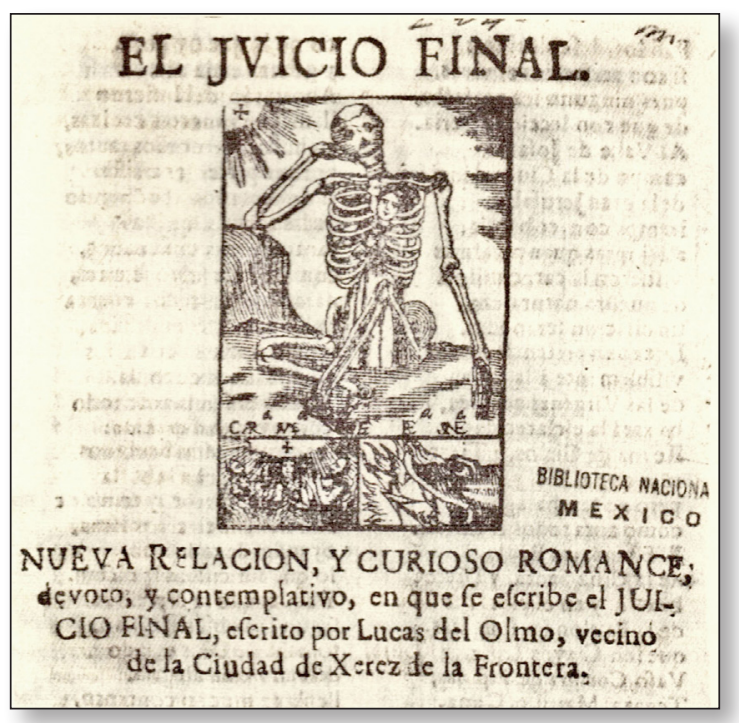

Fig. 5. Lucas del Olmo, El Juicio Final tomado de Galí, 2008 y 2013. 
[...] todo el concurso de las almas allí vistas, tanto de los condenados, como el que salvó se mira, darán bien estrecha cuenta de su buena o mala vida [...] venid, benditos, venid, de mi Padre, a gozar dichas de la bienaventuranza, y de mi Gloria adquirida [...] bajad, malditos, bajad, de mi Padre a las sombrías cavernas a ser del fuego tizones en llamas vivas (Olmo, ca. 1750-1800).

En ese punto, tanto el Romance como el Pia Desideria coinciden en la importancia de la purificación del alma, el desprendimiento de las pasiones y los placeres provenientes del cuerpo como el único medio para alcanzar la bienaventuranza eterna (Pérez, 2012: 126).

De la misma época es un lienzo de autor desconocido que debió inspirarse en los grabados del Romance puesto que presenta las escenas inferiores, pero fue objeto de una modificación más. En la parte superior se añadió la representación de una misa de difuntos flanqueada por dos de los más antiguos y efectivos intercesores celestiales: la Virgen del Carmen y san Francisco de Asís. Cada uno de ellos rescata ánimas del purgatorio con sus atributos característicos, el escapulario y el cordón, respectivamente, mientras el sacerdote levanta la hostia consagrada, alimento divino que recuerda el sacrificio de Cristo por la redención de la humanidad [fig. 6].

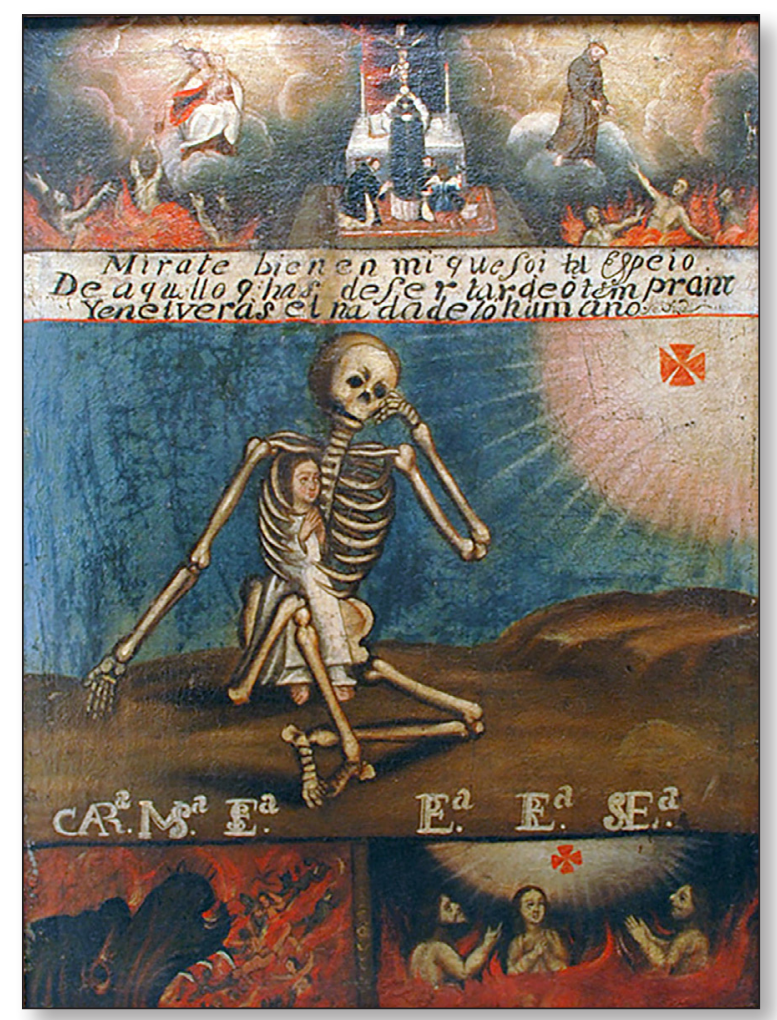

Fig. 6. Muerte, purgatorio e infierno, Colonial Arts Gallery, San Francisco, EE. UU.

Este agregado no podría ser más significativo pues refuerza el vínculo de los muertos con los vivos al ser estos quienes, a través de la oración, pueden disminuir el tiempo de las almas 
en el purgatorio. La inscripción -que tampoco era parte de modelos anteriores- lo confirma: «Mirate bien en mi que soi tu espejo de aquello q[ue] has de ser tarde o temprano y en el veras el nada de lo humano».

\section{DESEOS PROFANOS: EL MUERTO AL POZO Y EL VIVO AL GOZO}

En plena ilustración mexicana, la muerte y el más allá siguieron siendo una preocupación constante. En 1792 se publicó una obra que, si bien retoma el tema, pareciera marcar un parteaguas en la forma de abordarlo. La portentosa vida de la muerte, escrita por fray Joaquín Bolaños en 1792 tenía un carácter muy distinto de los libros doctrinales. ${ }^{14}$ Juan Pedro Viqueira aseguraba que este tratado «pretende combatir los avances de la incredulidad religiosa y la relajación de las costumbres morales [...] intenta asustar a los pecadores recordándoles constantemente su condición de mortales" (Viqueira, 1981: 29). Aunque, la finalidad del escrito coincide con aquellos de los siglos XVII, Bolaños alude a recursos distintos que él mismo explica en su prólogo:

La novedad que lleva esta obra la hallarás en la frente de estos capítulos: y con esta estratagema hemos querido captar tu benevolencia a su lectura. Hallarás en las bibliotecas muchos libros místicos muy superiores, que por diversos modos tratan de la Muerte, mas como la materia no es nada gustosa a quien está muy hallado en el mundo [...] te la presento [...] disfrazada con un retazo de chiste, de novedad o de gracejo. Va en forma de historia, porque quiero divertirte: lleva su poquita de mística porque también pretendo desengañarte; separa lo precioso de lo vil, aprovéchate de lo serio y ríete de lo burlesco (Bolaños, 1983). ${ }^{15}$

A pesar de las buenas intenciones de Bolaños, La Portentosa fue objeto de férreas críticas, especialmente impulsadas por José Antonio Alzate. Entre las objeciones que el científico expresó están justamente el estilo alegórico -ajeno a la simplicidad de las verdades religiosas- así como el modo gracioso en el que está escrita (Alzate, 1831: 22, 24). Sin embargo, el vínculo entre lo burlesco y la muerte estuvo lejos de desaparecer y más bien, se consolidó durante todo el siglo XIX y se manifestó en ejemplos como Las calaveras borrachas claman por el chinguirito (1836) [fig. 7].

Este impreso evidencia la persistencia de ciertas costumbres, y vicios, en torno a la muerte. A través del sueño del narrador, el lector ha sido transportado al cementerio de Santiago Tlatelolco donde se aparecen varios esqueletos que cuentan las razones de su muerte. Las apariciones sobrenaturales servían entonces para reafirmar la existencia del purgatorio, impulsar las acciones de los vivos para auxiliar a las almas sufrientes y dar una idea de quiénes habitaban esta morada (Lomnitz, 2005: 247); por ejemplo, en este caso encontramos a un borracho, un conquistador, un escribano, un militar y un hombre rico.

\footnotetext{
14. Se trata de una «novela que tiene como eje estructural a su protagonista, la Muerte, y que a partir de este pretexto va mostrando episodios y aventuras que nuestro personaje 'vive' en un mundo creado para él, y que desde luego hará al lector recapacitar sobre la fugacidad de la vida y la necesidad de estar preparado cuando llegue el momento de la muerte» (López de Mariscal, 1992: 23).

15. De acuerdo con Blanca López de Mariscal «la obra está matizada con un gran sentido del humor que pretende divertir, y la necesidad de novelar del autor se encuentra oculta entre una serie de sermones y reflexiones sobre el inminente fin del ser humano y la importancia de vivir en gracia de Dios. No habría salido a la luz de otra forma en 1792, cuando las posibilidades de llegar a la imprenta se encontraban tan restringidas» (1992: 36).
}

IMAGO, NÚM. II, 2019, I35-152 


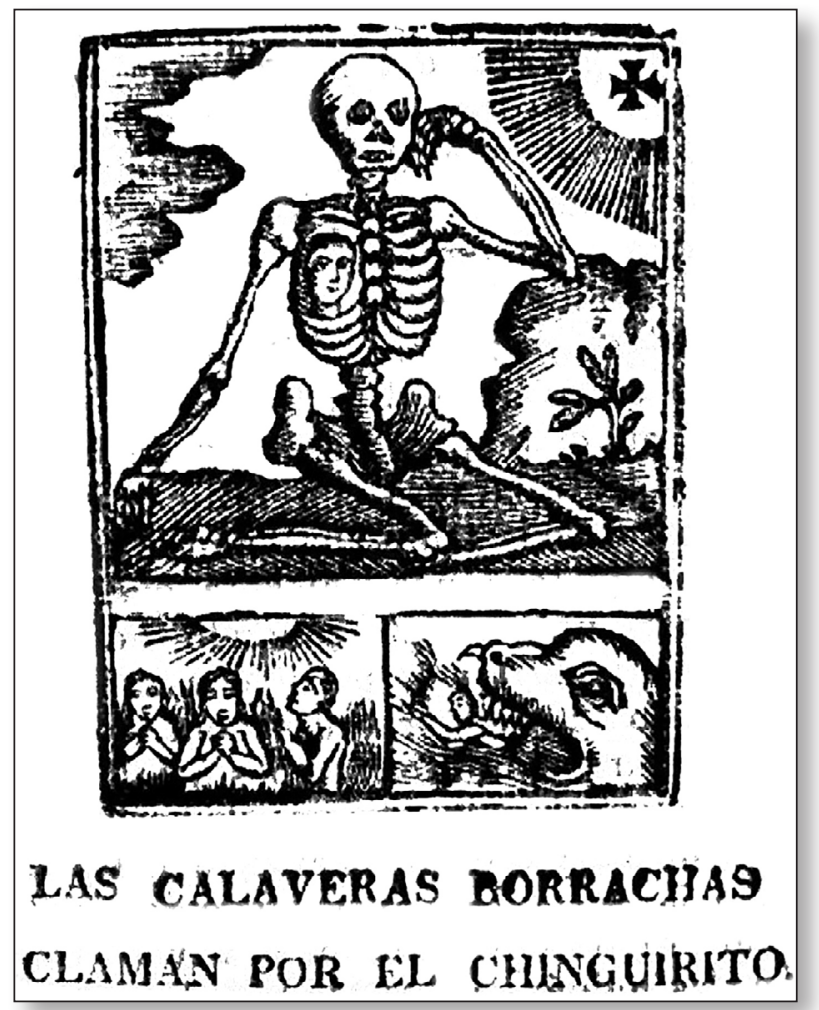

Fig. 7. Las calaveras borrachas claman por el chinguirito, 1836, Biblioteca Nacional, UNAM

Los años entre 1790 y 1860, coincidentes con las dos últimas publicaciones mencionadas, fueron un periodo de múltiples transformaciones políticas y sociales. Una de ellas fue la promoción de reformas a los lugares de entierro, sobre todo para terminar con las sepulturas dentro de las iglesias y confinar los camposantos a extramuros de las ciudades (Lomnitz, 2005: 276). Por lo cual, no es casual que el lugar de la manifestación onírica de Las calaveras borrachas sea el camposanto de Tlatelolco considerando que, apenas tres años antes de su publicación en 1836, algunos artículos periodísticos habían hecho notar cierta «fetidez en la atmósfera, atribuyéndola a las exhalaciones pútridas del cementerio de Santiago, porque los cadáveres no quedan bien sepultados" (El Fénix de la libertad, septiembre 1833: 4).

Por su parte, El Telégrafo aseguraba, en la misma fecha, que no debía «temerse contagio alguno ocasionado por la corrupción de los cadáveres puesto que están sepultados a bastante profundidad teniendo sobre sí una capa de cal y vara y media de tierra" (El Fénix de la libertad, septiembre 1833: 4). Esta disputa quizá responda al interés gubernamental por nombrar al atrio del convento de Santiago Tlatelolco como Cementerio General de la Ciudad de México en detrimento de panteones que ya no cumplían con las normas deseables de higiene, como el de San Lázaro (El Fénix de la libertad, diciembre 1833: 1-2). ${ }^{16}$ Como explica el investigador Claudio Lomnitz:

16. «Para diciembre de 1833 el gobierno de Valentín Gómez Farías expidió un bando de policía mediante el cual se prohibía cualquier entierro 'fuera quien fuera', dentro de la ciudad. Se designaba como cementerio general para 
[...] los modernizadores y tradicionalistas se valían rutinariamente de la imaginería de lo macabro para cruzar espadas en público [...] los modernizadores generaron una corriente continua de quejas relativas al hedor de los cadáveres en descomposición en la iglesia [...] A su vez, los moralistas tradicionalistas se valían de la imagen del cadáver en descomposición para infundir el temor de Dios en una generación que se apartaba de las formas de piedad tradicionales (Lomnitz, 2005: 274-275).

Sin embargo, en el impreso de Las calaveras se traslucen otras problemáticas sociales además de la higiene. Se mencionó anteriormente que uno de los cementerios propensos a ser clausurados fue el del leprosario de San Lázaro, el cual también era famoso por el abundante número de familias que los días 2 de noviembre acudían a los sepulcros "para comer y beber diluvios de espumoso pulque» (Vázquez Mantecón, 2015: 11). Esta costumbre fue de las más criticadas y combatidas desde finales del siglo XVIII ${ }^{17}$ debido a que "después de haber velado junto a las tumbas entre 'banquetes opíparos', riñas y jarros de pulque, (los deudos) comenzaban una 'orgía funeral' [...]» (Vázquez Mantecón, 2015: 11). En Las calaveras hay una alusión a este tema en los lamentos del primer esqueleto que interpela al narrador: « $¡ \mathrm{Oh}$ si no me hubiera entregado tanto al mal vicio de la embriaguez aún existiría en el mundo! Pero ¡ay de mí! Que yo mismo me violenté la vida con mis continuas borracheras y la perdí a la temprana edad de 21 años" (Las calaveras borrachas claman por el chinguirito, 1836).

Otro personaje incluido entre los cadáveres del camposanto de Santiago es un hombre acaudalado que al enfermar fue atendido por un afamado médico. Éste aparentó que el padecimiento era más grave con la finalidad de recibir un pago mayor, los malestares se agravaron y el hombre falleció. Un esqueleto más narró un caso similar, pues el boticario equivocó la medicina y aceleró su deceso. Es curioso notar que Bolaños había escrito una sátira similar en La portentosa vida de la muerte en la cual la Muerte llora el fallecimiento del médico Rafael Pimentel de la Mata "pues ha perdido una vida, que tantas vidas le ha dado» (Bolaños, 1983: 70) [fig. 8].

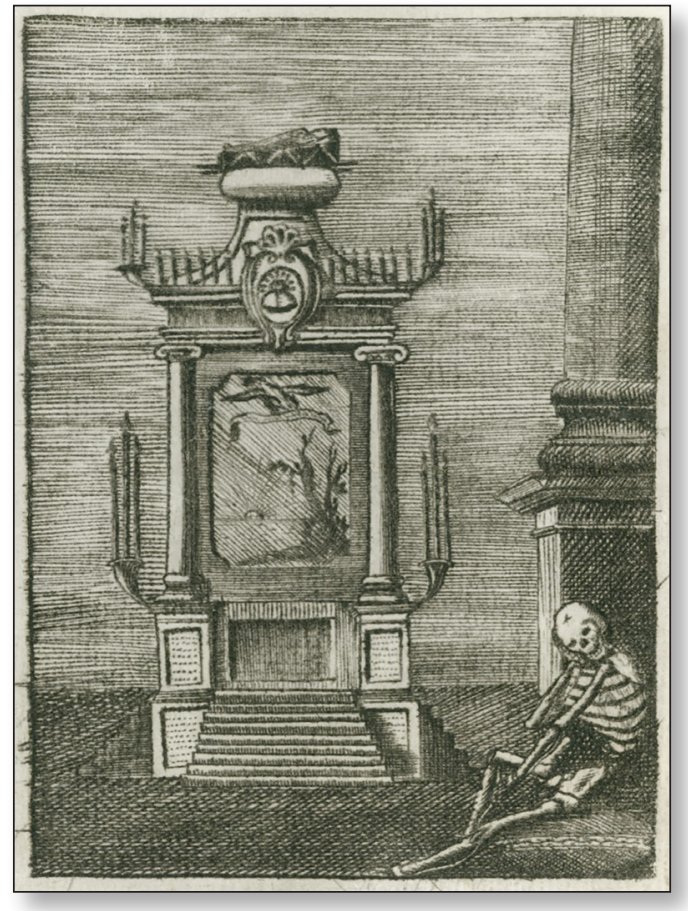

Fig. 8. Francisco Agüera Bustamante, «La Muerte llora el fallecimiento de su amigo el médico", La portentosa vida de la muerte, 1792.

\footnotetext{
la ciudad de México el atrio del convento de Santiago Tlatelolco, dentro de cuyos límites se harían dos secciones aparte, una para sacerdotes y otra para niños» (Staples, 1977: 16).

Incluso se establecía que el cementerio de san Lázaro debería clausurarse desde el 31 de diciembre de dicho año y el Cementerio General de Tlatelolco se abriría el 1 de enero de 1834 (El Fénix de la libertad, diciembre 1833: 1-2). 17. En 1766 se prohibió la asistencia a los cementerios y la venta de bebidas embriagantes después de las nueve de la noche (Vázquez Mantecón, 2015: 9). Es evidente que el problema siguió vigente ya que en 1790 se prohibió «el uso de comidas o banquetes peculiares en los días de entierros [...] (que no tienen) otro objeto que el de cohonestar sacrílegamente, a la sombra de la piedad, la embriaguez y el desorden con la concurrencia de ambos sexos» (Lomnitz, 2005: 251).
} 
Tampoco parece casual la elección de este profesionista si consideramos que desde varios años atrás los médicos y boticarios abusaban de la necesidad en épocas de enfermedad colectiva. Por ejemplo, en 1830 cuando las boticas aprovecharon un brote de viruela para cobrar hasta dos y medio o tres reales por servicios que no tendrían un costo mayor de dos octavos de real (El Sol, 1830: 807). Y tan sólo tres años antes de la publicación en 1836 de Las calaveras, la ciudad había sido víctima de una terrible epidemia de cólera de la que algunos habían sacado beneficio. Guillermo Prieto lo recordaría en Memorias de mis tiempos:

De tal manera dominaba el pánico, que se anunció que un sabio [...] había descubierto un parche que era preservativo infalible de la epidemia; esta medicina se atribuía a un químico, D. Manuel Herrera. La gente se agolpó de un modo tan ansioso y tumultuoso por aquel fiat de salvación de vida, que fue forzoso poner guardias numerosos en la casa del Sr. Herrera para evitar un desastre; pero caten Uds. ahí que en día menos pensado derrama en son de chisme, publica avisos, pega en las esquinas papeles y esparce alarmas alguien afirmando que los parches eran segurísimos pasaportes para la eternidad.

El pánico había invadido los ánimos, de manera que estaban en juego las medicinas y procedimientos más contradictorios. A una mujer del pueblo ordenó el Dr. Alarcón una sangría; la mujer interpretó la medicina tomándose un vaso de sangría y el resultado fue magnífico; el médico pedía la sangre y ella le decía que había dejado el vaso vacío (Prieto, 1906: 88-90).

Las calaveras no sólo retomaron ideas existentes desde finales del siglo XVIII sino también imágenes, al incorporar el emblema "Infelix ego homo!» de Pia Desideria. No obstante, parece más probable que la alegoría haya llegado a través del Romance de Lucas del Olmo. Las razones para pensar esto se deben a los tipos de literatura; mientras que el primero es un libro de emblemas en latín y -pese a su éxito- el círculo de lectores era reducido, el segundo formaba parte de un medio de comunicación mucho más accesible, tanto económico como intelectual. Aunado a ello, el grabado conserva las escenas inferiores del purgatorio y el infierno que no estaban presentes en el Pia Desideria.

De acuerdo con Montserrat Galí, entre los siglos XVI y XVIII los impresos populares con noticias maravillosas o truculentas fueron el material de lectura más difundido, en contraposición a los libros que eran caros, y a pesar de ser objetos muy apreciados, su producción y distribución era restringida (Galí, 2013: 32). Incluso, los llamados romances y coplas fueron prohibidos por Carlos III debido a que

[...] resultan impresiones perjudiciales en el público, además de ser una literatura van y de ninguna utilidad a la pública instrucción, pudiéndose dedicarse las personas de talento a escribir cosas provechosas, y que fomenten la Educación, el Comercio, las Artes y la Agricultura y todos los conocimientos útiles a la Nación [...] Por lo cual prohíbo [...] que se puedan imprimir Pronósticos, Romances de Ciegos y Coplas de Ajusticiados (Galí, 2013: 31-32).

Los temas que reproducían estas hojas volantes, entre los que se contaban las vidas de ladrones y forajidos, raptos de doncellas y asesinatos crueles, escandalizaban a las autoridades ilustradas. Lo mismo ocurría con las historias de supuestos milagros y apariciones de almas y condenados que «dañan la razón desde la misma infancia (y) la hacen el resto de la vida supersticiosa y crédula» (Galí, 2013: 32). Sin embargo, los esfuerzos por censurar estos materiales fueron infructuosos pues su producción no disminuyó, al contrario, se transformaron y alcanzaron su máxima expresión de la mano de grabadores como Posada y Manilla (Galí, 2013: 32, 35-36). 
Con respecto a las imágenes de esta literatura popular, Galí menciona que era común que se reciclara el material de antiguas imprentas debido a que los grabados eran caros (Galí, 2013: 32-33). Sin embargo, el caso de Las calaveras es distinto pues, aunque recupera la representación, el grabado no proviene de la misma plancha que los anteriores ya que hay notorios cambios estilísticos y algunas modificaciones en la composición. Podríamos pensar, quizás, como lo sugiere la misma autora en relación al trabajo de Posada, que frecuentemente «bastaba con una simple indicación escrita (o) en otros momentos sus mismos clientes le llevaban la muestra y el modelo a reproducir» (Galí, 2013: 344). Desafortunadamente, desconocemos el nombre del autor de Las calaveras y tampoco hay información sobre el trabajo del impresor Hipólito Lagarza, datos que podrían ayudar a despertar varias incógnitas acerca del bagaje cultural de ambos.

\section{CONSIDERACIONES FINALES}

«La imagen artística es un producto del artificio humano [...] soportado por un medio, que parte de un proceso creativo. Toda inteligencia de dicho proceso supone un acto interpretativo el cual será distinto ante la mirada profana y la experta pues para la primera forma parte de su cotidianeidad» (García Mahíques, 2009: 230-231). Esa dualidad nos permite acercarnos a la cotidianidad de un grupo social a través de expresiones visuales.

Con dicha finalidad he procurado trazar la trayectoria de una imagen que tuvo su origen visual en 1624 y que se mantuvo vigente, en la geografía mexicana, hasta 1832. En el ámbito europeo, existe una réplica aún más tardía, proveniente del libro de emblemas del poeta inglés Frances Quarles. Me detendré en esta obra pues también resulta un caso revelador. Si bien se publicó por primera vez en 1635 tuvo constantes reimpresiones; la última en $1888 .^{18}$ Desafortunadamente, la edición de 1635 que pude consultar tiene un error pues la imagen de los emblemas VIII y IX se repite cuando, en el primero, debería aparecer la alegoría que nos incumbe, por lo cual recurriré a la edición posterior de 1658.

Los Emblems de Quarles retomaron las pictura del Pia Desideria y los ejemplares producidos durante los siglos XVII y XVIII conservaron mucho del trazo y disposición de los grabados de Bolswert, sin embargo, las ediciones de 1800, 1861 y 1886 parecieran presagiar -desde su portada- la estética tan característica del decadentismo finisecular [figs. 9-11]. Baste recordar obras como Funambulesca de Julio Ruelas, que ilustra el poema homónimo de Amado Nervo y que parecen compartir sensibilidades con emblemas como «Ni mesme la mort» de Otto Vaenius, por supuesto con la diferencia del carácter "aterrador y sensual» del zacatecano (Ramírez, 2008: 143) o Alegoría de la Muerte de Roberto Montenegro en la cual la protagonista del escrito de Bolaños recupera su calidad de emperatriz [figs. 12-14]. ${ }^{19}$

\footnotetext{
18. Una búsqueda no exhaustiva arrojó por lo menos dieciséis ediciones posteriores a 1635, casi todas realizadas por impresores londinenses: John Williams \& Francis Eglesfeild, 1658; J. Williams, 1684; Matthew Gillyflower \& William Freeman, 1696; William Freeman, 1709; Nueva York: N. Tibbals \& Co., 1800; Chiswick Press, 1812 y 1818; J. Robins, 1824; J. Bennet, 1839; Milton Press, 1839; T. Tegg, 1845; Bradbury and Evans, 1845; Halifax: Milner \& Sowerby, 1851; James Nisbet \& Co., 1861 y 1886 y una más en Edimburgo: W. Paterson, 1888. Es importante aclarar que únicamente considero los ejemplares de Emblems pues existen otras ediciones en que se publicaron como un solo volumen junto con las obras Hieroglyphics of the life of man y/o The School of the Heart.

19. La afinidad no se limita a lo visual sino también a lo literario lo cual se vislumbra en el epigrama de Vaenius y los versos de Nervo: "Si la Dame à l'amant faait la guerrea à outrance,/ voire que par son feu le contraigne morir,/ l'Amant ne s'en reffent, ains aime de souffrir./ L'Amour mesme en la mort ne manque de constance» (Otto Vaenius).
} 


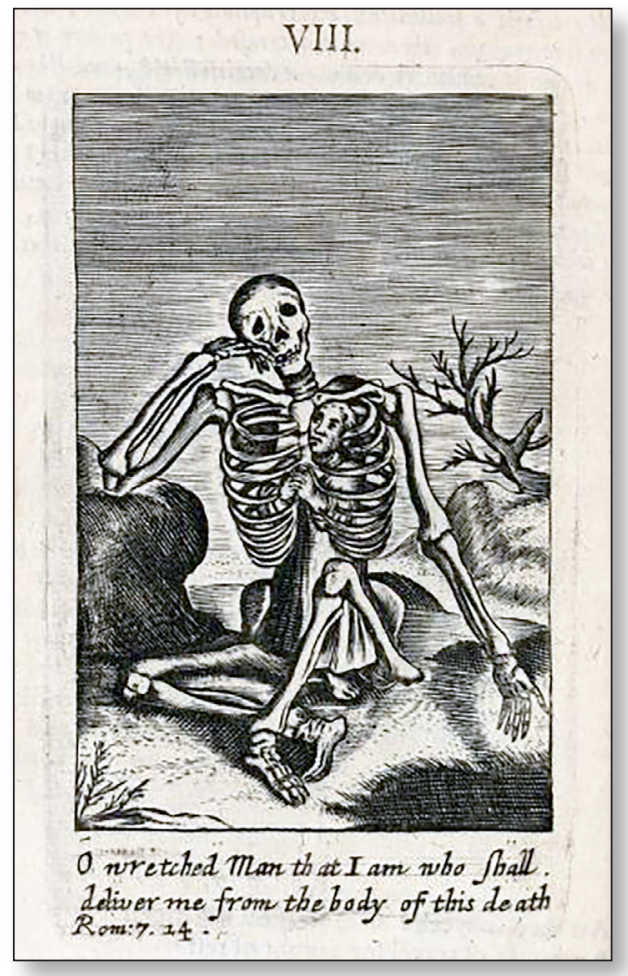

Fig. 9. Francis Quarles, Emblemes, Libro V, Emblema VIII, 1658.

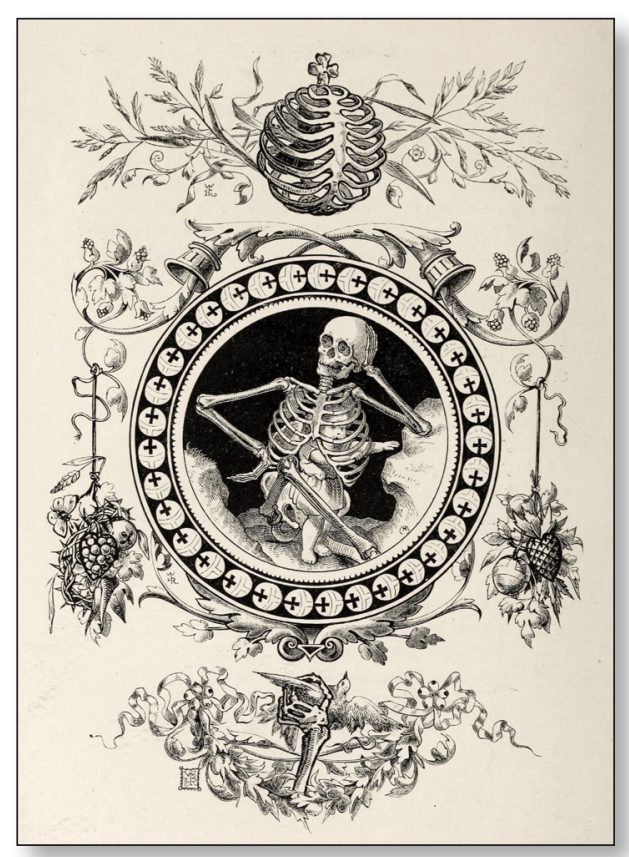

Fig. 11. Harry W. Rogers, 1800.

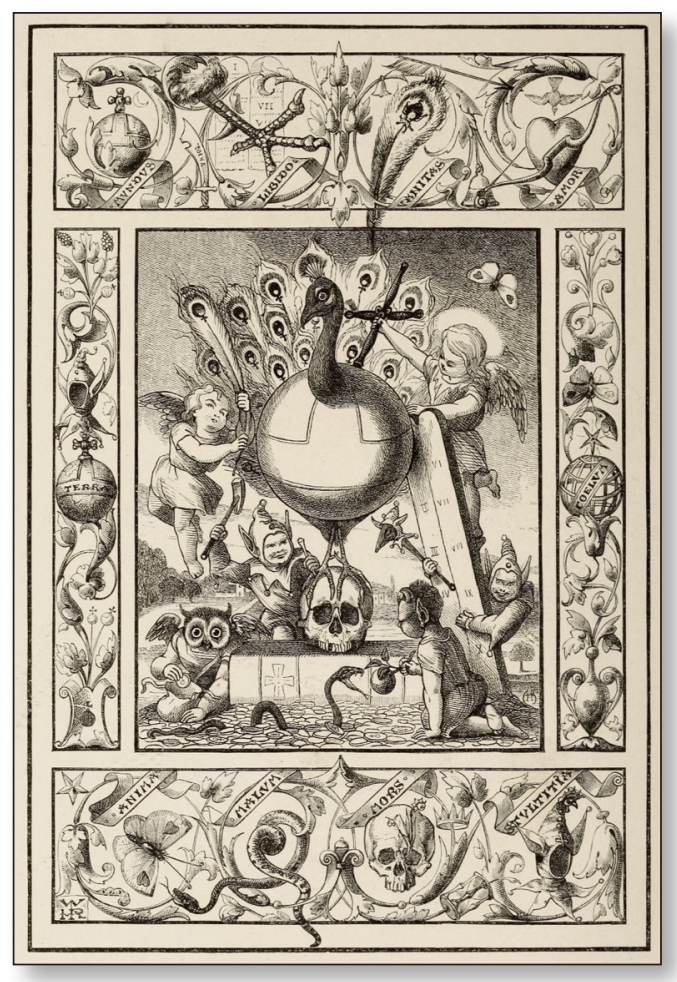

Fig. 10. Harry W. Rogers, frontispicio, Francis Quarles, Emblemes, 1800.

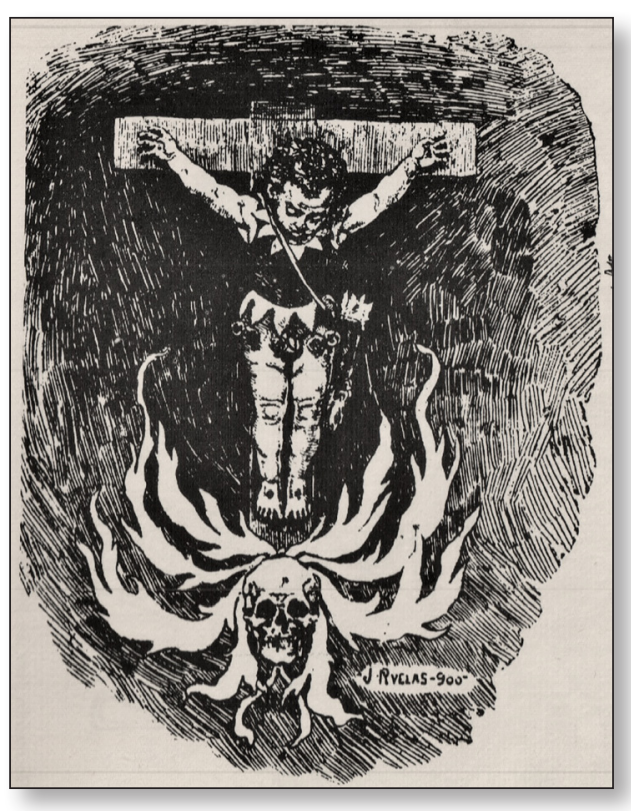

Fig. 12. Julio Ruelas, "Funambulesca», Revista Moderna, abril 1900, Hemeroteca Nacional Digital de México.

IMAGO, NÚM. I I, 2019, I 35-I52 


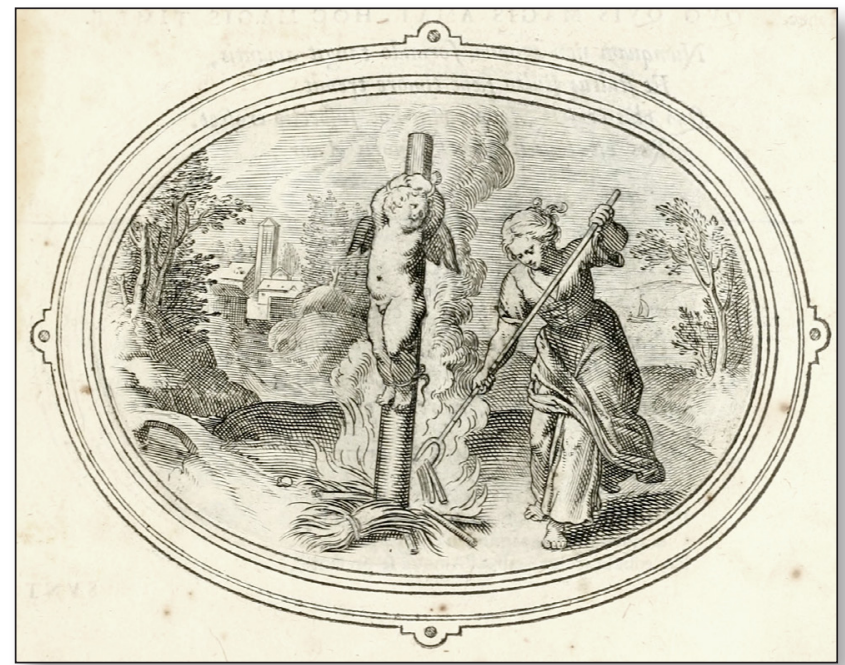

Fig. 13. «Ni mesme la mort», Otto Vaenius, Amorum Emblemata, 1608.

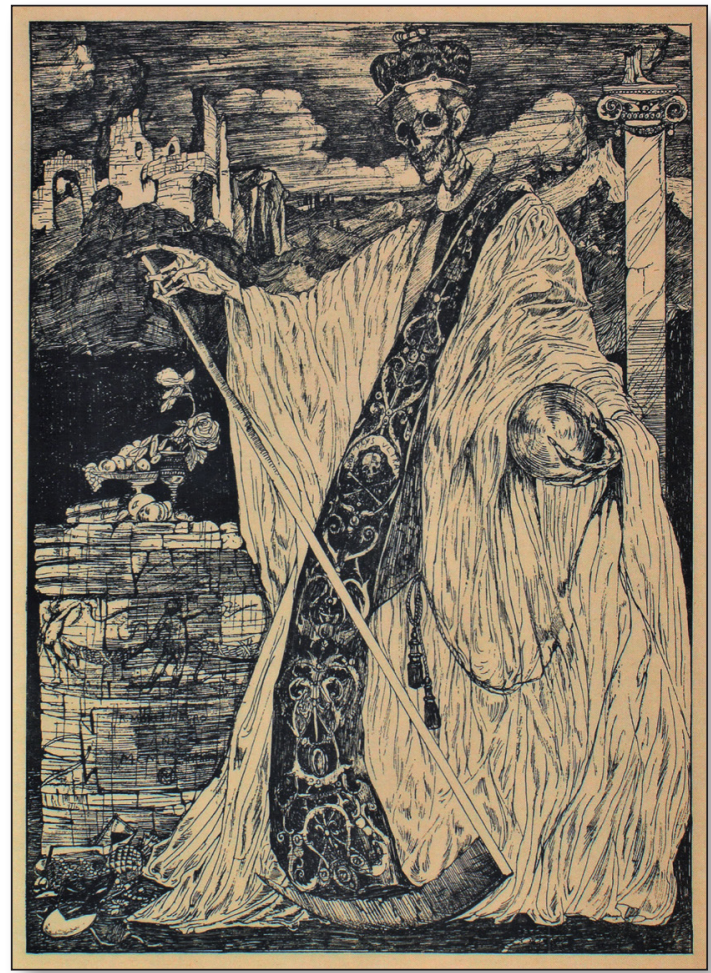

Fig. 14. Roberto Montenegro, «La mort», Vingt dessins, 1910.

«Mis pesares son alegres y mi dicha llanto vierte;/ son mis duelos danzarines y mis júbilos son frailes; / yo he sentido en los saraos la amargura de la muerte, / y he sentido ante la muerte la alegría de los bailes [...] Soy Heráclito y Demócrito a la vez, sol y nublado;/ sorbo ajenjos en las risas y en el llanto sorbo mieles, / y es el sueño de mis noches un amor crucificado/ que repica sollozando, muchos cascabeles" (Amado Nervo, Funambulesca, fragmento).

IMAGO, NÚM. II, 2019, 135-152 
Aunque las representaciones de «Infelix ego homo!» mantienen una iconografía relativamente estable, la mayoría de los ejemplos están en soportes y contextos muy distintos, salvo el modelo original y el más tardío que comparten el género literario. Tanto el romance del Juicio Final como Las calaveras borrachas pertenecen a la esfera de la estampa popular teniendo en consideración su amplia difusión incluyendo a los sectores subalternos, la tosquedad de la línea así como los contenidos temáticos (Galí, 2008: 67). No obstante, estos materiales de carácter popular que hacen referencia a publicaciones de otro orden revelan «de manera muy clara y evidente que nunca hubo una separación tajante entre ambos mundos (literatura culta y cultura popular) y, por el contrario, asistimos a préstamos, influencias y trasvases continuos" (Galí, 2008: 67).

En una primera lectura parecería que el texto de Las calaveras no guarda relación con la ilustración que le acompaña sin embargo propongo aquí algunas cuestiones. A reserva de saber más sobre el autor y su universo cultural, la imagen, aunque no es aludida abiertamente en el texto, podría ser una elección no tan aleatoria. A lo largo del siglo XIX, y desde finales del XVIII, la crítica literaria destiló bastante tinta para lanzar juicios higienistas en torno a la celebración de día de difuntos y, de manera implícita, sobre la concepción de la muerte en la época. Pues, tal como asevera Anne Staples:

El estado [...] como parte de la secularización tan vital para el funcionamiento de una sociedad moderna y pragmática, ha luchado por apartar a los muertos del exclusivo domino religioso. Ha aducido [...] razones de salud pública, de elemental higiene, de orden y control estadístico, pero también se aprecia por parte de las autoridades civiles una preocupación por disminuir la preponderancia del clero sobre los muertos, quienes no dejan de influir en los vivos (Staples, 1977: 15).

Un periodista de El Mundo expresó20 en 1895 que «la muerte entre los mexicanos seguía sirviendo de pretexto [...] para gozar la vida con mayor expansión que nunca» (Vázquez Mantecón, 2015: 3). El afamado escritor Ignacio Manuel Altamirano también se hizo escuchar; sentenció que "el 2 de noviembre en México no era más que 'una fiesta para los vivos', 'una cosa convenida', un 'motivo para pasear', de 'lucimiento', 'distracción' y, sobre todo, vanidad” (Vázquez Mantecón, 2015: 13). Los visitantes extranjeros emitieron opiniones similares; Carl L. Sartorius dijo que «los ritos en honor de los muertos eran alegres y no melancólicos», la condesa Kolonitz opinaba «que los días de Todos Santos y Difuntos en la ciudad de México eran cualquier cosa menos melancólicos, ni solmenes» (Vázquez Mantecón, 2015: 17).

Paradójicamente, vicios como los ya mencionados (vanidad, lucimiento, superficialidad) eran los mismos que tanto el Pia Desideria como el Romance de Lucas del Olmo buscaban combatir. En ese sentido, podríamos pensar, quizá, que la inclusión de la alegoría del cuerpo como cárcel del alma responda a la búsqueda de la melancolía y del ánimo doloroso y meditabundo que, se supone, debería predominar los días 1 y 2 de noviembre (Vázquez Mantecón, 2015: 17) pues «la alegoría [...] dentro del discurso del poder [...] forma parte de las herramientas didácticas que tratan de mantener la cohesión del orden cultural y social» (Méndez, 2006: 156). Otra idea a destacar es la mortificación de la carne debido a que ese elemento perecedero del hombre era el que más gozaba durante las conmemoraciones ya que la penitencia y piedad se habían remplazado por banquetes acompañados de chinguirito.

20. Aunque estos testimonios son posteriores a la fecha de publicación de Las calaveras el proceso al que hago referencia se gestaba desde finales del siglo XVIII. Ver (Lomnitz, 2005). 
De acuerdo con Mijail Bajtin, «la comicidad irreverente de la fiesta popular contenía un elemento de victoria [...] sobre la aprensión que inspiraría el más allá, las cosas sagradas y la muerte» (Vázquez Mantecón, 2015: 17), sin embargo, detrás de la apariencia burlesca la incertidumbre y solemnidad pervivían, tanto así que tras la epidemia de cólera de 1833:

[...] las mismas autoridades del ayuntamiento de la ciudad de México que encabezaron la reforma (de cementerios) solicitaron permiso de que los cadáveres de sus propios miembros, fuesen sepultados en la iglesia de Guadalupe como era costumbre, y se sintieron complacidos de ver que su solicitud fue concedida (Lomnitz, 2005: 276).

Y así, como declaraba el censor de Bolaños, cuando la muerte «se les presenta en todo el lleno de su terrible aspecto los aterra, confunde, y abate sus espíritus, sin que la fortaleza que aparentan sea capaz de disipar sus temores» (Bolaños, 1983).

\section{FUENTES Y BIBLIOGRAFÍA}

[1836]. Las calaveras borrachas claman por el chinguirito, México, Hipólito Lagarza.

Alzate, J. A. [1831]. Gacetas de literatura de México, tomo III, Puebla, Manuel Buen Abad.

BÁez, L. [2012]. "La fórmula Pathos (Pathosformel) en los programas emblemáticos de la casa editorial de Cristóbal Plantin», Pérez Martínez. H. y Skinfill, Nogal B. (eds.), Creación, función y recepción de la emblemática, México, El Colegio de Michoacán, 245-257.

Bolaños, J. [1983]. La portentosa vida de la muerte (1792), México, Instituto Nacional de Bellas Artes.

El FÉNIX DE LA LIBERTAD [10 de septiembre de 1833]. "Extracto de El Demócrata del 9 de septiembre», 4.

EL FÉNIX DE LA LIBERTAD [10 de septiembre de 1833]. «Extracto de El Telégrafo del 9 de septiembre», 4.

EL FÉNIX DE LA LIBERTAD [19 de diciembre de 1833]. «Distrito Federal», 1-2.

EL SOL [18 d enero de 1830]. «Distrito Federal», 807.

Galí, M. [2013]. Posada: 100 años de calavera, México: Fundación BBVA Bancomer, Editorial RM.

Galí, M. [2008]. La estampa popular novohispana, México, Taller de Grabado Erasto Cortés.

García MAHíques, R. [1992]. "Gemidos, deseos y suspiros: El programa místico de Santa Catalina de Arequipa", Boletín del Museo e Instituto Camón Aznar, 48-49, pp. 83-114.

García Mahíques, R. [2009]. Iconografía e iconología. Cuestiones de Método, Madrid, Encuentro.

Herman, H. [1624]. Pia Desideria. Amberes, Henrico Aertssen.

Herman, H. [1694]. Pia Desideria, Colonia, Theodor Kinchi.

Lomnitz, C. [2005]. Idea de la muerte en México, México, Fondo de Cultura Económica.

López de Mariscal, B. [1992]. Fray Joaquín Bolaños. La Portentosa vida de la muerte, edición crítica, introducción y notas, México, El Colegio de México.

Méndez, Sigmund [2006]. «Del Barroco como el ocaso de la concepción alegórica del mundo", Andamios, 2, 4, 147-180.

Morales Folguera, J.M. [2009]. "La celda del Padre Salamanca en el Convento de la Merced de Cuzco", Imago. Revista de emblemática y cultura visual, 1, pp.79-97.

Olmo, L. DeL. [ca.1750-1800]. Nueva relación y curioso romance, devoto y contemplativo, en que se escribe el Juicio Final. 
Pérez, L. [2012]. "El cuerpo como tumba en Filón de Alejandría. Uso y resignificación de una metáfora", Circe de clásicos y modernos, 16, 123-138.

Prieto, G. [1906]. Memorias de mis tiempos 1828 a 1849, México, Viuda de C. Bouret.

QuARLES, F. Emblemes, Londres: G.M., 1635;

QuARLES, F. Emblemes, Londres: John Williams \& Francis Eglesfeild, 1658.

Quarles, F. Emblemes, Londres: J. Williams, 1684.

Quarles, F. Emblems, Londres: Matthew Gillyflower \& William Freeman, 1696.

QuARLEs, F. Emblemes, Londres: William Freeman, 1709.

Quarles, F. Quarles' Emblems, Nueva York: N. Tibbals \& Co., 1800.

Quarles, F. Emblems. Divine and moral, Londres: Chiswick Press, 1812 y 1818.

Quarles, F. Emblems. Divine and moral, Londres: J. Robins, 1824

Quarles, F. Emblems. Divine and moral, Londres: J. Bennet, 1839.

Quarles, F. Emblems. Divine and moral, Londres: Milton Press, 1839.

Quarles, F. Emblems. Divine and moral, Londres: T. Tegg, 1845.

Quarles, F. Emblems. Divine and moral, Londres: Bradbury and Evans, 1845.

Quarles, F. Emblems. Divine and moral, Halifax: Milner \& Sowerby, 1851.

Quarles, F. Quarles' Emblems, Londres: James Nisbet \& Co., 1861 y 1886.

QuARles, F. Emblems. Divine and moral, Edimburgo: W. Paterson, 1888.

RAmírez, F. [2008]. Modernización y modernismo en el arte mexicano, México, Instituto de Investigaciones Estéticas-UNAM.

SALAS, P. [1658]. Affectos divinos con emblemas sagradas, Valladolid, Gregorio de Bedoya.

SEBAstián López, S. [1994]. "Los libros de emblemas: uso y difusión en Iberoamérica», CuADRIELlo J. y otros, Juegos de ingenio y agudeza. La pintura emblemática de la Nueva España, México, Museo Nacional de Arte, 56-82.

Sebastí́n López, S. [1981]. Contrarreforma y barroco, Madrid, Alianza.

StAPLes, A. [1977]. "La lucha por los muertos», Diálogos: Artes, Letras, Ciencias humanas, 13, $5,15-20$

Thesauro, M. [1741]. Cannochiale Aristotelico, tomo II, Madrid, Antonio Marín.

VÁzquez Mantecón, Mª del C. [2015]. «1 y 2 de noviembre en la ciudad de México, 17501900", Estudios de Historia Moderna y Contemporánea de México, 49, 1-18.

ViqueIra, J. P. [1981]. «El sentimiento de la muerte en el México ilustrado del siglo XVIII a través de dos textos de la época», Revista Relaciones, 5, 27-62.

ZAFrA, R. y AzAnZA, J. J. [2009]. "Deleitando enseña: Una lección de emblemática», <http:// Www.unav.es/biblioteca/fondoantiguo/hufaexp20/Deleitando_ensena/Portada.html> 18-04-25. 